\title{
Indirect effects of bioinvasions in Yellowstone Lake: the response of river otters to declines in native cutthroat trout
}

Jamie R. Crait, ${ }^{\mathrm{a},}$, Eric V. Regehr ${ }^{\mathrm{b}}$, Merav Ben-David ${ }^{\mathrm{a}}$

${ }^{a}$ Department of Zoology and Physiology, Program in Ecology, University of Wyoming, Laramie, Wyoming 82071, USA

${ }^{\mathrm{b}}$ US Fish and Wildlife Service, Marine Mammals Management, 1011 East Tudor Road, Anchorage, Alaska 99503, USA

"Corresponding author at: Life Sciences Program, 1000 E. University Avenue, University of Wyoming, Laramie, WY, USA. Tel.: +1 3077664207

E-mail address: craitj@uwyo.edu (J. Crait). 


\section{ABSTRACT}

Nonnative species threaten ecosystems throughout the world - including protected reserves. In Yellowstone National Park, river otters Lontra canadensis depend on native cutthroat trout as prey, but nonnative lake trout and whirling disease have significantly reduced the abundance of these native fish in the park's largest body of water, Yellowstone Lake. We studied the demographic and behavioral responses of otters to declining cutthroat trout on Yellowstone Lake and its tributaries. Over an eight-year period, we monitored otter activity at latrine (scentmarking) sites, collected scat for prey identification, and used individual genotypes from scat and hair samples to evaluate survival and abundance with capture-recapture methods. Otter activity at latrines decreased with declines in cutthroat trout, and the prevalence of these fish in otter scat declined from $73 \%$ to $53 \%$. Cutthroat trout numbers were the best predictor of temporal variation in apparent survival, and mean annual survival for otters was low (0.72). The density of otters in our study area (1 otter per $13.4 \mathrm{~km}$ of shoreline) was also low, and evidence of a recent genetic bottleneck suggests that otter abundance might have declined prior to our study. River otters in and around Yellowstone Lake appear to be responding to reductions in cutthroat trout via changes in distribution, diet, and possibly survival and abundance. Our results provide a baseline estimate for monitoring the broader outcome of management efforts to conserve native cutthroat trout and emphasize the indirect ecosystem consequences of invasive species.

Key words: aquatic-terrestrial linkages; capture-recapture; introduced species; noninvasive sampling; population size; spawning 


\section{Introduction}

Nonnative species are a leading threat to biodiversity (Wilcove et al., 1998). Successful invaders may assume the role of "strongly interacting species" (Soulé et al., 2005) by directly affecting endemics or via indirect effects on nutrient dynamics and ecosystem function (Mack et al., 2000). Furthermore, the effects of invaders in one ecosystem can be linked to ecological processes in an adjacent one (Knight et al., 2005). The establishment of formal reserves, such as national parks, may help attenuate the spread of nonnative species, but bioinvasions are a significant concern even in these relatively pristine settings (Loope, 2004).

Yellowstone National Park (YNP) has been one of the most protected natural areas in North America for over a century. Nonetheless, human-mediated invasions of nonnative species (e.g., Hall et al., 2006) have threatened habitats throughout the Greater Yellowstone Ecosystem (GYE). Recently, nonnative species created a potential ecological catastrophe in the park's largest body of water, Yellowstone Lake. Here, two aquatic invaders, lake trout (Salvelinus namaycush) and whirling disease (caused by the parasite Myxobolus cerebralis), led to a severe decline in the population of native Yellowstone cutthroat trout (Oncorhynchus clarkii bouvieri; Koel et al., 2005). Cutthroat trout were historically a dominant species in this ecosystem and prey for numerous birds and mammals (Gresswell, 2011). The decline in cutthroat trout has altered the lake's trophic structure and likely had propagating effects throughout the Yellowstone Lake food web (Gresswell, 2011; Middleton et al., 2013). However, few studies have quantified the effects of these invaders on top predators.

The GYE has historically been a refuge for North American river otters (Lontra canadensis) when habitat loss, water pollution, and over-harvest reduced their populations in other parts of the Rocky Mountain region (Boyle, 2006). Otters are one of several species in 
Yellowstone Lake that depend heavily on native cutthroat trout for prey, especially during summer when the fish migrate from the lake into tributary streams to spawn (Crait and BenDavid, 2006; Wengeler et al., 2010). Since the introduction of lake trout, the Yellowstone Lake cutthroat trout population has declined by more than 90\% (Koel et al., 2005; Teisberg et al., 2014). The lake supports relatively few fish species, and other potential prey are unlikely to provide a suitable replacement either because they are less abundant or because they have a lower energy value than trout (Crait and Ben-David, 2006). Moreover, introduced lake trout are less accessible to river otters because they inhabit deeper water and spawn in the lake rather than in streams (Koel et al., 2005). Continued declines in the availability of cutthroat trout could therefore reduce the abundance and distribution of otters around Yellowstone Lake.

To explore the effects of changes to the Yellowstone Lake food web on river otters, we monitored seasonal activity at latrine (scent-marking) sites, evaluated diet composition, and estimated survival and abundance via noninvasive genetic sampling of feces and hair. We predicted that (1) declines in the cutthroat trout population would reduce abundance and survival of river otters in the Yellowstone Lake watershed; (2) river otter activity levels would be lowest in areas of the lake ecosystem with the fewest cutthroat trout; and (3) concurrent with cutthroat trout declines, the frequency of other prey items in otter scats would increase during the study.

\section{Methods}

\subsection{Study area}

Detailed descriptions of the study area are available in Crait and Ben-David (2006, 2007).

Briefly, Yellowstone Lake is located in southeastern YNP, Wyoming, USA (Fig. 1). YNP has a temperate climate with a mean annual temperature of $0^{\circ} \mathrm{C}$. Summer and winter temperatures average $11.1{ }^{\circ} \mathrm{C}$ and $-10.8{ }^{\circ} \mathrm{C}$, respectively. Mean annual precipitation is $513 \mathrm{~mm}$ - primarily 
falling as snow in late fall and winter (Benson, 1961). Yellowstone Lake is a large (surface area $=341 \mathrm{~km}^{2}$; shoreline length $\left.=239 \mathrm{~km}\right)$ and deep $($ average $48.5 \mathrm{~m}$; maximum $133 \mathrm{~m})$, mesotrophic lake, located at high elevation $(2357 \mathrm{~m})$.

Yellowstone Lake supports two native fish species: Yellowstone cutthroat trout and longnose dace (Rhinichthys cataractae), as well as nonnative longnose sucker (Catostomus catostomus), redside shiner (Richardsonius balteatus), lake chub (Couesius plumbeus), and more recently, lake trout (Koel et al., 2005). In late spring and early summer, adult cutthroat trout migrate into $\sim 68$ of the 124 of the lake's tributaries to spawn. Spawning adults remain in streams from 1-3 weeks, and most migrate back to the lake after spawning (Gresswell, 2011).

Nonnative lake trout were first discovered in Yellowstone Lake in 1994, and have been breeding there since the mid to late 1980's (Koel et al., 2005). Individual lake trout consume an average 41 cutthroat trout per year (Ruzycki et al., 2003) and contributed to $\sim 60 \%$ declines in the cutthroat population within the lake between 1995 and 2004 (Koel et al., 2005). Whirling disease, which does not infect the nonnative lake trout, was first detected in Yellowstone Lake tributaries in 1998, possibly leading to a reduction in cutthroat trout recruitment (Koel et al., 2005 , 2006). The effect of these aquatic invaders has been especially pronounced in tributary streams. For example, spawning migrations to Clear Creek in the 1970s and 1980s were as high as 60,000-70,000 trout per year, but plummeted to an average of 3,828 fish between 2001 and 2004, and comprised less than 600 fish in 2006 and 2007 (Gresswell, 2011; Koel et al., 2012).

\subsection{Sample collection}

In 2002-2003 and 2006-2008 we surveyed, on foot and by boat, for otter latrines along the lake shoreline $(180 \mathrm{~km})$ and several tributaries (105 km; Fig. 1). Stream surveys included sections of the Yellowstone River from the lake's outlet to the Upper Yellowstone Falls; Pelican, 
Cub, Clear, Columbine, Otter, Bridge, and Arnica Creeks. Survey dates began in late May or early June and ended in late August, encompassing three periods: pre-, peak-, and post-spawning (Crait and Ben-David, 2006). Cutthroat trout spawning migrations are asynchronous among years and among tributary streams (Haroldson et al., 2005; Gresswell, 2011), so we adjusted the three period designations on a stream-by-stream and year-by-year basis (Crait and Ben-David, 2006). Spawning periods were determined from National Park Service (NPS) spawning counts and our own walking surveys on tributary streams (Crait and Ben-David, 2006). Each year, we visited latrines every 3-5 days during the field season. In 2005, we conducted a shorter field season during the last week of May and first two weeks of June (Crait et al., 2012). We also monitored latrine site activity over one-week periods in June 2009 and 2010, but these surveys were too brief for inclusion in the demographic analyses.

We monitored a total of 91 river otter latrines ( $n=39$ on Yellowstone Lake; $n=52$ on tributary streams; Fig. 1) during the study, and collected samples from 53 of these sites ( $n=28$ on Yellowstone Lake; $n=25$ on tributaries). At each latrine site, we counted old (deposited $>24$ $\mathrm{h}$ before the survey) and fresh scats (distinguished by distinct odor and appearance). Fresh scats and anal gland secretions were preserved in $100 \%$ ethanol and stored on ice. During the 20062008 field seasons, we placed 1-3 modified commercial body-snares (DePue and Ben-David, 2007) at latrines with heavy otter activity ( $>5$ scats per site). These snares capture hair from a single individual and thus avoid cross-contamination of samples. Samples were stored in paper envelopes and frozen. In 2005, we collected blood samples from five (four males, one female) live-trapped otters (Crait et al., 2012).

\subsection{DNA analysis}


Details on DNA extraction, polymerase chain reaction (PCR), and genotyping are provided in Appendix S1. Briefly, we extracted DNA from river otter blood, feces, and hair follicles, and amplified the DNA with PCR using standard protocols. We scored eight microsatellite loci to distinguish among individual otters, including three tetranucleotide (Rio01, Rio17, and Rio19) and one trinucleotide (Rio05) markers developed for river otters (Beheler et al., 2004, 2005), and four tetranucleotide markers (Lut701, Lut733, Lut801, and Lut829) developed for Eurasian otters (Lutra lutra; Dallas and Piertney, 1998). In addition, we used the LutSRY locus for sex identification (Dallas et al., 2000). To ensure that we correctly identified individuals, we analyzed each sample in triplicate, and followed the comparative multiple-tubes approach (Frantz et al., 2003). Although this conservative approach to genotyping may have produced a "shadow effect" (i.e., failure to differentiate between unique individuals with identical genotypes), population estimators are less biased by the shadow effect than by the occurrence of genotyping error (Mills et al., 2000; Frantz et al., 2003).

Standard tests of genotyping error, Hardy-Weinberg Equilibrium (HWE), and probability of identity (PID) are described in Appendix S1 and Table S1. We used the Bayesian clustering program STRUCTURE 2.2 (Pritchard et al., 2000) to identify subpopulations of otters in the study area (Appendix S1). We evaluated the occurrence of a recent population bottleneck with the software BOTTLENECK 1.2.02 (Cornuet and Luikart, 1996). Although both the number of alleles and heterozygosity decline following a bottleneck event, the number of alleles falls at a greater rate (Cornuet and Luikart, 1996). Therefore, BOTTLENECK tests for a significant number of loci with heterozygote excess. We used Wilcoxon sign-rank to test for a bottleneck under the assumption of the infinite alleles model (IAM) and stepwise mutation model (SMM). 
The two phase model (TPM), which tests allele mutation intermediate between the IAM and SMM models (Pickles et al., 2012), was also used and set to 70\% SMM.

\subsection{Demography}

We explored the demography of Yellowstone Lake river otters by fitting capturerecapture models to individual capture histories based on genotypes obtained from feces and hair (Lukacs and Burnham, 2005). We pooled individual identifications from repeated visits into monthly capture occasions (June, July, and August) and limited analyses to years during which each site was sampled at least once per month (2002-2003 and 2006-2008). This established a uniform sampling area, a consistent delineation of the study population, and likely reduced overdispersion of data (Guertin et al., 2012). The final capture history matrix consisted of 15 monthly sampling occasions. We then introduced capture histories into Cormack-Jolly-Seber (CJS) models for open populations with unequal time intervals (Lebreton et al., 1992; Cooch and White, 2015). CJS models use maximum likelihood to estimate values of apparent survival ( $\varphi$, the probability of remaining alive and within the study population) and recapture probability $(p)$ that best explain the observed individual capture histories.

Model selection followed information theoretic methods (Burnham and Anderson, 2002). We constructed an a priori candidate model set based on combinations of biologically meaningful structures and covariates for $\varphi$ and $p$. We considered three types of time variation in $\varphi$. First, we evaluated a time-constant structure [i.e., $\varphi($.$) per Lebreton et al. (1992)]. We did not$ include full time dependence in either $\varphi$ or $p$ [i.e., $\varphi(t)$ per Lebreton et al. (1992)] because of practical limitations on the number of parameters that can be estimated from sparse data. Second, we considered a time-varying structure with $\varphi$ as a linear function (on the logit scale) of precipitation in the study area during the months June, July, and August (the covariate precip; 
National Climatic Data Center, Wyoming Climate Division 1; http://lwf.ncdc.noaa.gov).

Previous studies have found that climatic factors can affect the abundance of otters and their prey (e.g. Ruiz-Olmo et al., 2011; Albeke et al., 2015), so the precip covariate was included to test the hypothesis that apparent survival of otters was related to drought conditions present during the study (Koel et al., 2005; Teisberg et al., 2014). Finally, we modeled $\varphi$ as a linear function of the annual number of spawning trout in Clear Creek (the covariate spawners; Koel et al., 2012), which we assumed was representative of cutthroat trout abundance throughout our study area. This reflects the hypothesis that apparent survival of otters was related to abundance of their primary prey (Crait and Ben-David, 2006). In all models, we allowed $\varphi$ to differ for males and females (the covariate sex) based on proposed sex-specific differences in natural survival and movement patterns of river otters (Melquist et al., 2003). Including models with additive effects resulted in the following four parameterizations for $\varphi$ : $\varphi(\operatorname{sex}), \varphi($ sex + spawners $), \varphi($ sex + precip $)$, and $\varphi($ sex + precip + spawners $)$.

We considered two types of time variation in $p$. First, we evaluated a time-constant structure [i.e., $p()$.$] . Second, we included a time-varying structure with p$ as a linear function of sampling intensity (the covariate effort) based on the annual number of observer visits to latrine sites. Because some latrine sites were easily accessed (e.g., those near a road or trailhead), we also considered an individual covariate (access) calculated from the proportion of occasions an otter was located at an easy-to-access latrine site. This covariate likely explained individual heterogeneity in $p$ associated with the observation process, and therefore reduced potential bias in parameter estimates (Pollock et al., 1990). Finally, we allowed $p$ to differ for male and female otters based on possible sex-specific differences in intensity of latrine site use and aversion to hair snares (Ben-David et al., 2005). Including models with additive effects resulted in the 
following seven parameterizations for $p$ : $p($ sex $), p($ effort $), p($ access $), p($ effort + access $), p($ sex + effort $), p($ sex + access $), p($ sex + effort + access $)$.

The candidate model set consisted of 28 models based on combinations of the parameterizations for $\varphi$ and $p$ described above. We evaluated goodness-of-fit (GOF) for the most-supported model using the parametric bootstrap GOF test within program MARK (White and Burnham, 1999), and estimated a variance inflation factor $(\hat{c})$ by comparing the original model deviance with that from 1000 simulated datasets (Cooch and White, 2015). Relative support for candidate models was evaluated using Akaike's Information Criterion corrected for small sample size and overdispersion (i.e., QAIC ${ }_{\mathfrak{c}}$; Burnham and Anderson, 2002). Parameter estimates were derived from model averaging (Burnham and Anderson, 2002) over the five models with $\Delta$ QAIC $_{\mathrm{c}}<5$ (Table 1). Annual estimates of $\varphi$ were derived from monthly estimates using the delta method to estimate variances (Cooch and White, 2015). We assessed the importance of certain covariates by summing the $\mathrm{QAIC}_{\mathrm{c}}$ weights of models containing those covariates in the final model suite (Burnham and Anderson, 2002).

We derived indices of annual abundance $(N)$ using a Horvitz-Thompson equation (McDonald and Amstrup, 2001) by averaging recapture probabilities for June, July and August (except for 2002, when only July and August values were available). We generated the sampling distribution for indices of $N$ using a bootstrap procedure with 500 simulated datasets created by resampling individual capture histories with replacement (e.g., Regehr et al., 2010). Finally, we used linear regression of $\log (N)$ among years to estimate mean observed annual population growth rate $\lambda$ (Fryxell et al., 2014). We fitted CJS models with 'mra' package (McDonald 2015) and implemented it in the R-language (R Development Core Team, 2015). 
For comparison with estimates derived from CJS models, and with data reported in similar river otter studies (e.g., Mowry et al., 2011), we also estimated abundance with program Capwire (Miller et al., 2005). Capwire is frequently used in noninvasive genetics sampling because it allows the input of multiple captures within a sampling period, accounts for capture heterogeneity and sampling intensity, and is tractable for small populations $(<100$ individuals; Miller et al., 2005; Brøseth et al., 2010). We used the likelihood ratio test $(P<0.10)$ within Capwire to choose between the even capturability model (ECM; no heterogeneity) and the two innate rates model (TIRM; heterogeneity present) for each year of the study. Because Capwire assumes a closed population, lack of closure could result in Capwire abundance estimates that are biased high (Sugimoto et al., 2014).

We calculated otter densities by dividing estimated abundance by the length of stream and lake shoreline surveyed (Palmeirim et al., 2014). River otters rarely travel more than $100 \mathrm{~m}$ from water for extended periods (Bowyer et al., 2003), so length of waterway represents a better measure of otter distribution than area (Melquist and Hornocker, 1983).

\subsection{Space use and latrine site activity}

We plotted individual otter locations at latrines on a digital map with ArGIS 10 (ESRI, Redlands, CA; Fig. 1) and used scat-counts to estimate changes in latrine use during the study. We calculated distance traveled as the average distance between recaptures of individual otters on subsequent occasions. We also estimated daily movement as the distance between all latrines that otters visited divided by the number of days between first and last capture of that animal. In lieu of auxiliary data (e.g., from radiotelemetry), our measurements of distance traveled represent an index of otter movement. We conducted these analyses separately for males and females because of possible differences in home range size (Bowyer et al., 2003). 


\subsection{Diet analysis}

To assess otter diet, we identified prey materials (e.g., bones, scales, and feathers) after washing feces through a fine-mesh sieve (Crait and Ben-David, 2006). We were only able to distinguish between cutthroat and lake trout remains in 141 of 621 scats because bones with interspecific morphological differences (i.e., cranial) were often damaged or absent. We recorded the frequency of occurrence of prey types in scats for each sampling period and estimated $95 \%$ confidence intervals from the binomial distribution.

\section{Results}

\subsection{DNA analysis}

Overall genotyping success was $32 \%$ for scats $(n=422)$ and $41 \%$ for hair follicles $(n=$ 299). Annual success rates ranged from $30-46 \%$, except for $16 \%$ in 2002 . Seven of the microsatellite loci were polymorphic with two to five alleles (Table S1). The locus Rio19 was monomorphic in $>90 \%$ of samples and was discarded from further analyses. The multilocus $P_{\mathrm{ID}-\text { unbiased }}$ Was $4.23 \times 10^{-5}$ and $P_{\mathrm{ID}-\text { sibs }}$ (Waits et al., 2001) was $1.15 \times 10^{-2}$ indicating that all seven microsatellite loci, plus LutSRY, were needed to confidently differentiate between individuals (Table S1). Genotyping error rates included allelic dropout of $8.9 \%$ and false alleles of $0.9 \%$, with an overall multilocus average of $9.8 \%$ (Table S1). Heterozygosity was moderate $\left(H_{\mathrm{O}}=\right.$ $\left.0.51 ; H_{\mathrm{E}}=0.56\right)$ and a weak but significant departure from HWE was observed at one locus (Rio05; $P=0.04$ ) after Bonferroni correction. In addition, a weak but significant deviation from HWE was detected across the pooled loci $(P=0.04)$. Multilocus $F_{\text {IS }}$ was $0.07(P=0.03)$, suggesting some inbreeding within the Yellowstone Lake population or a possible Wahlund effect (Hobbs et al., 2011). We identified a single panmictic population from STRUCTURE analyses and evidence of a bottleneck based on heterozygote excess under the IAM model 
(Wilcoxon test; $P=0.007$ ) and TPM model (Wilcoxon test; $P=0.015$ ), but not the SMM model (Wilcoxon test; $P=0.109$ ).

\subsection{Demography}

We successfully genotyped 58 individual otters during the study period, with 29 individuals identified on multiple capture occasions and 29 identified only once. The male-tofemale ratio in the sample was 1.9:1.0. The number of individual otters identified per latrine site ranged from 0 to 18 (Fig. 1). The average number of captures per individual was 3.58 and ranged from 1 to 19 . In all, 40 otters (69\%) were captured in one year only, seven otters (12\%) in two years, eight (14\%) in three years, two (3\%) in four years, and one otter was caught in five different years.

The most supported CJS model $\varphi($ sex + spawners $) p($ effort $)$ included five parameters (Table 1). The bootstrap GOF test produced an estimate of $\hat{c}=1.16$ for this model, suggesting an adequate fit to the data. Inclusion of the covariate spawners in the most supported model [Model 1 in Table $1 ; \hat{\beta}_{\text {spawners }}=0.69, S E\left(\hat{\beta}_{\text {spawners }}\right)=0.40$ ] suggested a positive relationship between apparent survival $(\varphi)$ of otters and an index of cutthroat trout numbers. Similarly, the

covariate effort in this model $\left[\hat{\beta}_{\text {effort }}=1.28, S E\left(\hat{\beta}_{\text {effort }}\right)=0.26\right]$ suggested a positive relationship between recapture probability $(p)$ and sampling effort. By contrast, inclusion of the covariate sex in the best supported model $\left[\hat{\beta}_{\text {sex }}=-0.17, S E\left(\hat{\beta}_{\text {sex }}\right)=0.48\right]$ indicated little support for sex-specific differences in $\varphi$. Summed QAIC $_{c}$ weights for models including spawners was 0.69 , compared to 0.31 for models with time-constant $\varphi$, and 0.22 for models including the covariate precip in the $\varphi$ parameterization (Table 2). For female otters, model-averaged estimates of annual $\varphi$ declined from $0.87(95 \% \mathrm{CI}=0.64-1.0)$ in 2002 to $0.54(95 \% \mathrm{CI}=0.15$ 0.94) in 2008. Annual estimates for males were on average $8.4 \%$ lower than for females. The 
best estimate of mean $\varphi$ for females, derived from the most supported model with time-constant $\varphi$ (Model 2 in Table 1) was $0.72(95 \% \mathrm{CI}=0.53-0.90)$.

Effort was the most influential covariate for $p$, with a summed $\mathrm{QAIC}_{\mathrm{c}}$ weight of 0.90 in the $p$ parameterizations (Table 2). Monthly estimates of $p$ were lower in 2002-2003 (mean $p=$ 0.16) than 2006-2008 (mean $p=0.58$ ), and were similar for males and females (mean percent relative difference $<1 \%$ ). Based on indices of abundance from the CJS models, the median estimate of $\lambda$ was $0.92(95 \% \mathrm{CI}=0.69-1.65)$. Estimates of $\lambda$ near 1.0 suggest that the population may have been relatively stable; however, low precision of abundance estimates in early years (for both CJS and Capwire models) resulted in low statistical power to detect trends (Fig. 2). Because sampling effort and genotyping success were highest in 2008, we used the estimated abundance (from the Horvitz-Thompson equation) from that year to derive the most current and accurate value of otter density. Based on $285 \mathrm{~km}$ of shoreline, we estimated 1 otter/13.4 km $(95 \% \mathrm{CI}=1$ otter/10.1-20.4 km) as a baseline density for Yellowstone Lake and its tributaries.

\subsection{Space use and latrine site activity}

Otter activity (feces per site) declined significantly on several tributary streams (average $=2.2 \mathrm{feces} / \mathrm{site}$ in 2002 and 0.1 feces/site in 2008), and the lake shoreline (6.4 feces/site in 2002 and 2.3 feces/site in 2008), during the study (Kruskal-Wallis tests; $P<0.05$; Fig. 3A). In addition, latrine site densities declined on tributaries (average $=0.8$ latrines $/ \mathrm{km}$ in 2002 and 0.2 latrines/km in 2008; Kruskal-Wallis tests; $P<0.05)$, but remained similar on the lake shoreline (average $=0.2$ latrines $/ \mathrm{km}$; Kruskal-Wallis test; $P>0.05 ;$ Fig. 3B). The limited surveys in 2009 and 2010 indicated similar latrine densities and activity levels to those found in 2008. The location of otters on subsequent capture occasions showed that movement distances were lower in 2002-2005 (4.2 km $\pm 2.8 \mathrm{SE})$ than 2006-2008 (10.4 km $\pm 2.1 \mathrm{SE}$, Mann-Whitney test; $Z$ 
$=-2.032, P=0.04 ;$ Fig. S1). In general, individual otters lacked fidelity to one drainage or region of Yellowstone Lake, and moved throughout the study area each summer (Fig. 1). The largest straight-line distance between encounters occurred in 2007 when a female otter moved $35.3 \mathrm{~km}$ between the Yellowstone River on 5 July and southeastern Yellowstone Lake on 4 August. The distance traveled between latrine sites by otters was lower during the peak of cutthroat trout spawning $(5.5 \mathrm{~km} \pm 1.3 \mathrm{SE})$ than the post-spawning period $(9.4 \mathrm{~km} \pm 7.2 \mathrm{SE}$; $t$ test; $P=0.028$; Fig. S2). In addition, the distance traveled between latrine sites per day was greater for males $(0.92 \mathrm{~km} / \mathrm{day} \pm 0.18 \mathrm{SE})$ than females $(0.33 \mathrm{~km} /$ day $\pm 0.07 \mathrm{SE}$; Mann-Whitney test; $Z=-3.889, P<0.001)$.

\subsection{Diet analysis}

Trout (identified only to family level) remained the dominant prey type in otter scats, but their prevalence declined between $2003(73 \%)$ and $2008\left(53 \% ; \chi^{2}=8.05 ; P<0.005 ;\right.$ Fig. 4).

During the study, reductions in the prevalence of trout in otter scats were compensated for by an increase in amphibians ( $5 \%$ to $\left.19 \% ; \chi^{2}=12.49 ; P<0.001\right)$ and suckers $\left(37 \%\right.$ to $48 \% ; \chi^{2}=2.42$; $P=0.10$ ). Species-level identification of trout remains showed that, in summers 2002 and 2003, cutthroat and lake trout occurred in $95.5 \%$ and $4.5 \%$ of scats, respectively (Crait and Ben-David, 2006). For the summers of 2006-2008, we were able to distinguish between cutthroat trout and lake trout in 31 of the 106 analyzed scats. Of this subsample, cutthroat trout were found in $93.5 \%$, and lake trout in $6.5 \%$, of otter scats.

\section{Discussion}

Our results suggest that river otters in Yellowstone Lake responded to the reduced availability of cutthroat trout via changes in their activity levels and by supplementing their diet with alternative prey. Despite prey shifting, diet analyses conducted over a six-year span 
illustrate that native trout remained an important food source. Additionally, our findings support the hypothesis that declines in apparent survival of otters in Yellowstone Lake may be related to the availability of spawning cutthroat trout. Although we did not detect a numerical response, otter densities were low, and evidence of a recent genetic bottleneck suggests the population may have declined prior to the onset of our study.

\subsection{Effects of cutthroat trout decline on otter population dynamics}

Not unexpectedly, our estimates of apparent survival $(\varphi)$ were somewhat lower than the few published values of true survival for river otter populations (e.g., 0.76 in Oregon, Tabor and Wight, 1977; 0.87 in coastal Alaska, Bowyer et al., 2003). Estimates of $\varphi$ do not differentiate between true survival and site fidelity, so annual declines in $\varphi$ may have reflected permanent emigration from the population or nonrandom patterns in temporary emigration (Kendall et al., 1997). We found that individuals readily moved throughout our study area rather than showed fidelity to a particular region of Yellowstone Lake. Thus, our sampled population may have included residents (animals that inhabited the study area throughout the year) as well as transient individuals or animals with home ranges that partially overlapped our study area (Haroldson et al., 2005).

The evidence of positive relationship between $\varphi$ and numbers of spawning cutthroat trout is biologically plausible given the preponderance of these fish in otter diets in this study and previous ones (Crait and Ben-David, 2006; Wengeler et al., 2010). Despite drought conditions during the study, annual precipitation explained relatively little additional variation in estimates of $\varphi$. We suggest that this is because $\varphi$ was more proximately related to cutthroat abundance, which in turn may have corresponded with precipitation levels as mediated through other ecological processes (Koel et al., 2005). Estimates of $\varphi$ in the later years of the study appear too 
low to support a stable population (Boyle, 2006; Björklund and Arrendal 2008). However, our estimates of $N$ in early years of the study were associated with high sampling variation, which resulted in relatively wide confidence interval around the estimate of $\lambda(95 \% \mathrm{CI}=0.69-1.65)$ and thus a limited ability to infer trends in population growth. Such uncertainty is common in capture-recapture studies of carnivores at low densities and with small sample sizes (DevenishNelson et al., 2010). In our study, large confidence intervals in the early years likely reflected lower genotyping success and sampling effort, as well as the fact that we did not implement hair snaring until 2006.

It is also possible that the estimates of both $\varphi$ and $N$ were influenced by individual heterogeneity in recapture probability $(p)$. Although the covariate access explained important variation across individual otters in susceptibility to capture, un-modeled heterogeneity —if present — could lead to spurious associations with explanatory covariates that exhibit a monotonic trend (Devineau et al., 2006). In our study, such effects were likely mitigated by relatively high recapture probabilities (Cooch and White, 2015), especially in the later years when genotyping success improved. Interestingly, sex did not have a significant effect on $p$ or $\varphi$ despite a male-biased sex ratio in the capture sample. Sex ratios skewed towards male otters have been observed in several other studies (e.g., Melquist and Hornocker, 1983; Mowry et al., 2011). Although this finding is often attributed to higher capture probabilities for males (Melquist and Hornocker, 1983), Lauhachinda (1978) found a male-biased sex ratio of 173:100 in fetuses of pregnant otters. If the higher number of male otters in our sample reflected a skewed sex ratio in the underlying population, it could result from a preponderance of male births. 
In river otters, juvenile survival is usually lower than that of adults. For example, annual survival rates in Oregon were $0.68,0.46$, and 0.76 for age-classes 0,1 , and $2-11$, respectively (Tabor and Wight, 1977). Unfortunately, we could not estimate age-specific survival and may have underestimated survival of adult females - often the key determinant of $\lambda$ in otter populations (Boyle, 2006). Matrix demographic models for Eurasian otters (Björklund and Arrendal, 2008) and river otters (Boyle, 2006) demonstrated that survival $>0.70$ was necessary to maintain a stable population size. Declining juvenile $\varphi$ during our study period could partially explain the contrasting relationship between decreasing $\varphi$ and a seemingly stable otter population.

Our density estimate of $1 \mathrm{otter} / 13.4 \mathrm{~km}$ shoreline is among the lowest reported for a river otter population (e.g., Melquist and Hornocker, 1983; Mowry et al. 2011; Fig. S3). It is possible that otter numbers were historically low in Yellowstone Lake even prior to declines in cutthroat trout numbers. Indeed, otter abundance is often lower, and home ranges larger, in regions with limited resource availability and harsh abiotic conditions, which are typical of higher latitudes and elevations (Reid et al., 1994a). For example, in northeast Spain, Eurasian otter abundance and breeding success was negatively correlated with elevation, and in turn, altitudinal decreases in ecosystem production and prey availability (Ruiz-Olmo et al., 2011). In addition, Melquist and Hornocker (1983) found that otters in Idaho preferred stream habitats to lakes, likely because streams provide better shelter than more exposed lake shorelines. Otters may avoid areas with abundant food if they do not also provide adequate cover (Melquist and Hornocker, 1983). Given that more than $60 \%$ of our study area was composed of lake shoreline, it may be that low densities in our study area were partially a function of the lacustrine environment. 
The cutthroat trout population in Yellowstone Lake had already declined markedly by the time we initiated our research in 2002 , so significant decreases in otter abundance may have already occurred. This possibility is supported by evidence of a genetic bottleneck in the Yellowstone Lake otter population. The decrease in allele frequencies relative to heterozygosity which immediately follows a bottleneck can persist in a population for several dozen generations (Cornuet and Luikart, 1996). However, the power to detect this phenomenon is low after about 10 generations (Peery et al., 2012). Based on otter generation time (Bowyer et al., 2003), this suggests that any bottleneck event in our study population occurred within the last 30 years.

Interestingly, studies of the Eurasian otter (e.g., Randi et al., 2003; Hobbs et al., 2011) and giant otter (Pteronura brasiliensis; Pickles et al., 2012) did not detect bottlenecks in populations known to have recently declined. On the other hand, Hájková et al. (2007) identified bottlenecks in otter populations from the Czech and Slovak Republics and suggested they arose from large declines in abundance over a short duration. In addition, sea otter (Enhydra lutris) populations, which were historically exploited heavily in the fur trade, provide well-documented evidence of genetic bottlenecks (Larson et al., 2002). Thus, it is possible that the recent bottleneck event in the Yellowstone Lake river otter population, coinciding with a dramatic decline in cutthroat trout, was rapid and severe.

\subsection{Effects of cutthroat trout decline on otter behavior}

Otters displayed clear behavioral changes in terms of scent-marking activity and prey selection. Temporal changes in latrine activity on tributary streams were likely in response to declines in cutthroat trout, because latrines are often associated with key foraging areas (Melquist and Hornocker, 1983). Indeed, during the period of our investigation, tributaries such as Clear Creek experienced a $>95 \%$ reduction in cutthroat trout, while spawning runs ceased in 
Pelican Creek (Koel et al., 2012). We suggest that otters responded to decreased availability of spawning cutthroat trout by reducing their activity at latrine sites on tributaries, and in some cases, abandoning these latrines altogether.

Reduced fidelity to latrines could be a particularly important finding because it lends support to the hypothesis that the observed declines in apparent survival were a function of temporary or permanent emigration from the study area. Even within the effective study area we found evidence that otters increased the distance traveled in the later years of the study, possibly in response to declining cutthroat trout. Indeed, otter movement and home range size are often governed by resource availability (Reid et al., 1994a). For example, in Idaho, river otter activity was restricted during the kokanee (Oncorhynchus nerka) spawning season, but movement rates increased when the fish became less accessible (Melquist and Hornocker, 1983). In addition, Almeida et al. (2012) hypothesized that in some regions of Europe, declines in prey abundance could contribute to otter dispersal into previously unoccupied habitats. Future studies could more precisely quantify the link between otter movements and cutthroat trout distribution with alternative methods, such as telemetry.

Although otters may have increased movement within and out of the study area, during the spawning season cutthroat trout remained a seasonally important resource. During this period, otters continued to restrict their movement and concentrate activity on those tributary streams still supporting spawning cutthroat trout. This pattern is consistent with previous reports of otters using streams with readily-accessible spawning salmonids (Melquist et al., 2003). In Yellowstone, the seasonal accessibility of large, energy-rich cutthroat trout may be especially important to female otters with pups. Pup-rearing females have high energy demands associated 
with lactation and weaning, and their distribution may be tied to foraging areas with access to these lipid-rich prey (Crait and Ben-David, 2006).

Consistent with patterns of scent-marking activity, cutthroat trout remains were prevalent in otter scats during the critical pup-rearing period. However, the overall dominance of trout in scats declined by $20 \%$ from 2003 to 2008 , and otters supplemented their diet with alternative prey - mainly longnose suckers and amphibians. Despite evidence of prey-switching, suckers and amphibians may not be comparable replacement foods for Yellowstone Lake otters. For instance, boreal chorus frogs (Pseudacris maculata) and Columbia spotted frogs (Rana luteiventris) were the main amphibians in Yellowstone otter scats, but their availability may be limited to months when they are active (July and August). By contrast, suckers are probably an important prey throughout the year in Yellowstone Lake (Wengeler et al., 2010), but their energy content is lower than that of trout (Ruzycki et al., 2003). In addition, suckers are not as abundant in tributaries during the otter pup-rearing period (Crait and Ben-David, 2006).

The scarcity of nonnative lake trout in otter scats supports earlier findings (Crait and BenDavid, 2006; Wengeler et al., 2010) that these fish typically occur at depths beyond the foraging range of otters and are not a viable substitute for native cutthroat trout. Additionally, Yellowstone Lake otters may be further constrained in their ability to capture deep-water prey due to lower oxygen availability at high elevation (Crait et al., 2012). Studies in other lakes with lake trout likewise reported an absence of these fish in otter scats (Sheldon and Toll, 1964; Reid et al. 1994b). Furthermore, our results are consistent with those from other areas in YNP. For example, Wengeler et al. (2010) found that otters rarely eat lake trout in Lewis Lake (located only $\sim 10 \mathrm{~km}$ from Yellowstone Lake) which has supported a population of these nonnative fish for more than a century. Taken together, these findings suggest that Yellowstone otters may be 
uniquely dependent on cutthroat trout and are limited, both ecologically and physiologically, to few alternative prey species.

\subsection{Implications for conservation of aquatic-terrestrial linkages and ecosystem management}

The value of restoring "novel" ecosystems, those altered by human actions and dominated by invasive species, to their historical state has been the center of recent debate given the complexity and magnitude of the effort required (Simberloff et al., 2013; Hobbs et al., 2014). Less often has this debate addressed the consequences of mitigating biological invasions in one ecosystem on linked ecological processes in an adjacent one. For example, river otters transfer aquatically-derived nutrients to terrestrial habitats via their scent-marking behavior at latrines and create "hot spots" of nutrient heterogeneity at the water-land interface (Ben-David et al., 2005; Crait and Ben-David, 2007; Roe et al., 2010). Our finding of behavioral changes in latrine use suggest that the spatial distribution of these hot spots may have shifted away from tributary streams. These results corroborate a growing body of evidence that nonnative species in Yellowstone Lake have affected multiple components of the adjacent terrestrial ecosystem (Middleton et al., 2013; Teisberg et al., 2014). Given the ubiquity of aquatic invasions (Rahel, 2000), our study illustrates the need to assess the value of ecosystem restoration not only in situ but also for the connectivity and functioning of multiple ecosystems.

Finally, our results substantiate the utility of noninvasive sampling for addressing multiple aspects of the ecology of rare and elusive species - including diet, demography, and behavior. From a management perspective, such data could help conservation efforts to further understand the permeating, and often decades-long influence of biological invasions. Latrinemarking species such as the river otter may be particularly tractable for monitoring, because once activity sites are identified, sampling and long-term monitoring is feasible even in remote 
locations and with little specialized training in sample collection. Currently the NPS is implementing an aggressive and costly lake trout suppression program aimed at conserving the native cutthroat trout population (Koel et al., 2012). However, the effects of this suppression program transcend the Yellowstone Lake boundary. The baseline estimates we report here for river otters can aid in evaluating the success of the NPS lake trout suppression program on the function of the interlinked lake and riparian ecosystems of Yellowstone Lake and serve as a model for similar programs across the globe.

\section{Acknowledgements}

We thank N. Bowersock, J. Boyd, J. Boyer, G. Campbell, J. Herreman, Z. Holden, C. Huyler, T. McClean, R. McDonald, K. Ott, S. Schaefer, C. Stansbury, and M. Trana for assistance in the field and laboratory. A. Barocas, J. DePue, M. Kauffman, R. Landis, D. McDonald, and A. Ulseth provided helpful suggestions on methodology. Two anonymous reviewers provided valuable comments on earlier versions of this manuscript. We are grateful to Yellowstone National Park, especially P. Bigelow, T. Coleman, B. Ertel, K. Gunther, C. Hendrix, T. Koel, D. Mahony, and C. Smith, for logistical support. This research was funded by EPA Grant R829426E01, NSF Grant EPS-0447681, the University of Wyoming-National Park Service Research Center, and the Department of Zoology and Physiology at the University of Wyoming. The findings and conclusions in this article are those of the authors and do not necessarily represent the views of the US Fish and Wildlife Service.

\section{Appendix A. Supplementary material}

Supplementary data associated with this article can be found, in the online version

\section{References}


Albeke, S.E., Nibbelink, N.P, Ben-David, M., 2015. Modeling behavior by coastal river otter (Lontra canadensis) in response to prey availability in Prince William Sound, Alaska: a spatially-explicit individual-based approach. PLoS One 10, e0126208.

Almeida, D., Copp, G.H., Masson, L., Miranda, R., Murai, M., Sayer, C.D., 2012. Changes in the diet of a recovering Eurasian otter population between the 1970s and 2010. Aquat. Conserv. 22, 26-35.

Beheler, A.S., Fike, J.A., Dharmarajan, G., Rhodes, O.E., Serfass, T.L., 2005. Ten new polymorphic microsatellite loci for North American river otters (Lontra canadensis) and their utility in related mustelids. Mol. Ecol. Notes 5, 602-604.

Beheler, A.S., Fike, J.A., Murfitt, L.M., Rhodes, O.E., Serfass, T.L., 2004. Development of polymorphic microsatellite loci for North American river otters (Lontra canadensis) and amplification in related mustelids. Mol. Ecol. Notes 4, 56-58.

Ben-David, M., Blundell, G.M., Kern, J.W., Maier, J.A.K., Brown, E.D., Jewett, S.C., 2005. Communication in river otters: creation of variable resource sheds for terrestrial communities. Ecology 86, 1331-1345.

Benson, N.G., 2006. Limnology of Yellowstone Lake in relation to the cutthroat trout. US Dept. Interior Fish and Wildlife Service Research Report 56. pp. 1-33.

Björklund, M., Arrendal, J., 2008. Demo-genetic analysis of a recovering population of otters in Central Sweden. Anim. Conserv. 11, 529-534.

Bowyer, R.T., Blundell, G.M., Ben-David, M., Jewett, S.C., Dean, T.A., Duffy, L.K., 2003. Effects of the Exxon Valdez oil spill on river otters: injury and recovery of a sentinel species. Wildlife Monogr. 153, 1-53. 
Boyle, S., 2006. North American river otter (Lontra canadensis): a technical conservation assessment (ed R.M.R. USDA Forest Service).

Brøseth, H., Flagstad, Ø., Wärdig, C., Johansson, M., Ellegren, H., 2010. Large-scale noninvasive genetic monitoring of wolverines using scats reveals density dependent adult survival. Biol. Conserv. 143, 113-120.

Burnham, K.P., Anderson, D.R., 2002. Model Selection and Multimodel Inference. SpringerVerlag, New York.

Burnham, K.P., Anderson, D.R., White, G.C., Brownie, C., Pollock, K.H., 1987. Design and analysis methods for fish survival experiments based on release-recapture. Am Fish S Monogr. 5, Bethesda, Maryland, USA.

Cooch, E.G., White, G.W., 2015. Program MARK: A Gentle Introduction, 14th ed. Colorado State University, Fort Collins, CO, USA.

Cornuet, J.M., Luikart, G., 1996. Description and power analysis of two tests for detecting recent population bottle-necks from allele frequency data. Genetics 144, 2001-2014.

Crait, J.R., Ben-David, M., 2006. River otters in Yellowstone Lake depend on a declining cutthroat trout population. J. Mammal. 87, 485-494.

Crait, J.R., Ben-David, M., 2007. Effects of river otter activity on terrestrial plants in trophically altered Yellowstone Lake. Ecology 88, 1040-1052.

Crait, J.R., Prange, H.D., Marshall, N.A., Harlow, H.J., Cotton, C.J., Ben-David, M., 2012. High-altitude diving in river otters: coping with combined hypoxic stresses. J. Exp. Biol. $215,256-263$. 
Dallas, J.F., Carss, D.N., Marshall, F., Koepfli, K.-P., Kruuk, H., Piertney, S.B., Bacon, P.J., 2000. Sex identification of the Eurasian otter Lutra lutra by PCR typing of spraints. Conserv. Genet. 1, 181-183.

Dallas, J.F., Piertney, S.B., 1998. Microsatellite primers for the Eurasian otter. Mol. Ecol. 7, $1248-1251$.

DePue, J.E., Ben-David, M., 2007. Hair sampling techniques for river otters. J. Wildlife Manage. 71, 671-674.

Devenish-Nelson, E.S., Harris, S., Soulsbury, C.D., Richards, S.A., Stephens, P.A., 2010. Uncertainty in population growth rates: determining confidence intervals from point estimates of parameters. PLoS One 5, e13628.

Devineau, O., Choquet, R., Lebreton, J.-D., 2006. Planning capture-recapture studies: straightforward precision, bias, and power calculations. Wildlife Soc. B. 34, 1028-1035.

Frantz, A.C., Pope, L.C., Carpenter, P.J., Roper, T.J., Wilson, G.J., Delahay, R.J., Burke, T., 2003. Reliable microsatellite genotyping of the Eurasian badger (Meles meles) using faecal DNA. Mol. Ecol. 12, 1649-1661.

Fryxell, J.M., Sinclair, A.R.E., Caughley, G., 2014. Wildlife Ecology, Conservation, and Management, third ed. Wiley-Blackwell, Hoboken, NJ, USA.

Gresswell, R.E., 2011. Biology, status, and management of the Yellowstone cutthroat trout. N. Am. J. Fish. Manage. 31, 782-812.

Guertin, D.A., Ben-David, M., Harestad, A.S., Elliott, J.E., 2012. Fecal genotyping reveals demographic variation in river otters inhabiting a contaminated environment. J. Wildlife Manage. 76, 1540-1550. 
Hájková, P., Pertoldi, C., Zemanová, B., Roche, K., Hájek, B., Bryja, J., Zima, J., 2007. Genetic structure and evidence for recent population decline in Eurasian otter populations in the Czech and Slovak Republics: implications for conservation. J. Zool. 272, 1-9.

Hall, R.O., Dybdahl, M.F., VanderLoop, M.C., 2006. Extremely high secondary production of introduced snails in rivers. Ecol. Appl. 16, 1121-1131.

Haroldson, M.A., Gunther, K.A., Reinhart, D.P., Podruzny, S.R., Cegelski, C., Waits, L., Wyman, T., Smith, J., 2005. Changing numbers of spawning cutthroat trout in tributary streams of Yellowstone Lake and estimates of grizzly bears visiting streams from DNA. Ursus 16, 167-180.

Hobbs, G.I., Chadwick, E.A., Bruford, M.W., Slater, F.M., 2011. Bayesian clustering techniques and progressive partitioning to identify population structuring within a recovering otter population in the UK. Front. Ecol. Envir. 12, 557-564.

Hobbs, R.J. et al., 2014. Managing the whole landscape: historical, hybrid, and novel ecosystems. J. Appl. Ecol. 48, 1206-1217.

Kendall, W.L., Nichols, J.D. \& Hines, J.E., 1997. Estimating temporary emigration using capture-recapture data with Pollock's robust design. Ecology 78, 563-578.

Knight, T.M., McCoy, M.W., Chase, J.M., McCoy, K.A., Holt, R.D., 2005. Trophic cascades across ecosystems. Nature 437, 880-883.

Koel, T.M., Arnold, J.L., Bigelow, P.E., Doepke, P.D., Ertel, B.D., Ruhl, M.E., 2012. Yellowstone Fisheries \& Aquatic Sciences: Annual Report, 2011. National Park Service, Yellowstone Center for Resources, Yellowstone National Park, Wyoming, YCR-201203. 
Koel, T.M., Bigelow, P.E., Doepke, P.D., Ertel, B.D., Mahony, D.L., 2005. Nonnative lake trout result in Yellowstone cutthroat trout decline and impacts to bears and anglers. Fisheries $30,10-19$.

Koel, T.M., Mahony, D.L., Kinnan, K.L., Rasmussen, C., Hudson, C.J., Murcia, S., Kerans, B.L., 2006. Myxobolus cerebralis in native cutthroat trout of the Yellowstone Lake ecosystem. J. Aquat. Anim. Health. 18, 157-175.

Larson, S., Jameson, R., Etnier, M., Fleming, M., Bentzen, P., 2002. Loss of genetic diversity in sea otters (Enhydra lutris) associated with the fur trade of the 18th and 19th centuries. Mol. Ecol. 11, 1899-1903.

Lauhachinda, V., 1978. Life history of the river otter in Alabama with emphasis on food habits. PhD Dissertation, Auburn University, Auburn, Alabama.

Lebreton, J.-D., Burnham, K.P., Clobert, J., Anderson, D.R., 1992. Modeling survival and testing biological hypotheses using marked animals: a unified approach with case studies. Ecol. Monogr. 62, 67-118.

Loope, L., 2004. The challenge of effectively addressing the threat of invasive species to the National Park System. Park Sci. 22, 14-20.

Lukacs, P.M., Burnham, K.P., 2005. Review of capture-recapture methods applicable to noninvasive genetic sampling. Mol. Ecol. 14, 3909-3919.

Mack, R.N., Simberloff, D., Lonsdale, W.M., Evans, H., Clout, M., Bazzaz, F.A., 2000. Biotic invasions: Causes, epidemiology, global consequences, and control. Ecol. Appl. 10, 689710.

McDonald, T.L., Amstrup, S.C., 2001. Estimation of population size using open capturerecapture models. J. Agr. Biol. Envir. St. 6, 206-220. 
McDonald, T.L., 2015. mra: analysis of mark-recapture data, R package version 2.16.4. Available at http://CRAN.R-project.org/package=mra.

Melquist, W.E., Hornocker, M.G., 1983. Ecology of river otters in west central Idaho. Wildlife Monogr. 83, 1-60.

Melquist, W.E., Polechla, P.J., Jr., Toweill, D., 2003. River otter: Lontra canadensis, in: Feldhamer, G.A., Thompson, B.C., Chapman, J.A. (Eds.), Wild Mammals of North America: Biology, Management, and Conservation. Johns Hopkins University Press, Baltimore, MD, USA, pp. 708-734.

Middleton, A.D., Morrison, T.A., Fortin, J.K., Robbins, C.T., Proffitt, K.A., White, P.J., McWhirter, D.E., Koel, T.M., Brimeyer, D.G., Fairbanks, W.S., Kauffman, M.J., 2013. Grizzly bear predation links the loss of native trout to the demography of migratory elk in Yellowstone. P. Roy. Soc. Lond. B Bio. 280, 20130870.

Miller, C.R., Joyce, P., Waits, L.P., 2005. A new method for estimating the size of small populations from genetic mark-recapture data. Mol. Ecol. 14, 1991-2005.

Mills, L.S., Citta, J.J., Lair, K.P., Schwartz, M.K., Tallmon, D.A., 2000. Estimating animal abundance using noninvasive DNA sampling: promise and pitfalls. Ecol. Appl. 10, 283294.

Mowry, R.A., Gompper, M.E., Beringer, J., Eggert, L.S., 2011. River otter population size estimation using noninvasive latrine surveys. J. Wildlife Manage. 75, 1625-1636.

Palmeirim, A.F., Peres, C.A, Rosas, F.C.W., 2014. Giant otter population responses to habitat expansion and degradation induced by a mega hydroelectric dam. Biol. Conserv. 174, 3038. 
Peery, M.Z., Kirby, R., Reid, B.N., Stoelting, R., Doucet-Beer, E., Robinson, S., VasquezCarrillo, C., Pauli, J.N., Palsboll, P.J., 2012. Reliability of genetic bottleneck tests for detecting recent population declines. Mol. Ecol. 21, 3403-3418.

Pickles, R.S.A., Groombridge, J.J., Zambrana Rojas, V.D., Van Damme, P., Gottelli, D., Ariani, C.V., Jordan, W.C., 2012. Genetic diversity and population structure in the endangered giant otter, Pteronura brasiliensis. Conserv. Genet. 13, 235-245.

Pollock, K.H., Nichols, J.D., Hines, J.E., Brownie, C. 1990. Statistical inference for capturerecapture experiments. Wildlife Monogr. 107, 1-97.

Pritchard, J.K., Stephens, M., Donnelly, P., 2000. Inference of population structure using multilocus genotype data. Genetics 155, 945-959.

R Development Core Team, 2015. R: A language and environment for statistical computing. $\mathrm{R}$ Foundation for Statistical Computing, Vienna, Austria. ISBN 3-900051-07-0, URL http://www.R-project.org/.

Rahel, F.J., 2000. Homogenization of fish faunas across the United States. Science 288, 854-856.

Randi, E., Davoli, F., Pierpaoli, M., Pertoldi, C., Madsen, A.B., Loeschcke, V., 2003. Genetic structure in otter (Lutra lutra) populations in Europe: implications for conservation. Anim. Conserv. 6, 93-100.

Regehr, E.V., Hunter, C.M., Caswell, H., Amstrup, S.C., Stirling, I., 2010. Survival and breeding of polar bears in the southern Beaufort Sea in relation to sea ice. J. Anim. Ecol. 79, 117127.

Reid, D.G., Code, T.E., Reid, A.C.H., Herrero, S.M., 1994a. Spacing, movements, and habitat selection of the river otter in boreal Alberta. Can. J. Zoolog. 72, 1314-1324. 
Reid, D.G., Code, T.E., Reid, A.C.H., Herrero, S.M., 1994b. Food-habits of the river otter in a boreal ecosystem. Can. J. Zoolog. 72, 1306-1313.

Ritchie, E.G., Elmhagen, B., Glen, A.S., Letnic, M., Ludwig, G., McDonald, R.A., 2012.

Ecosystem restoration with teeth: what role for predators? Trends Ecol. Evol. 27, 265271.

Roe, A. M, Meyer, C. B., Nibbelink, N. P., Ben-David, M., 2010. Differential tree and shrub production in response to fertilization and disturbance by coastal river otters in Alaska. Ecology 91, 3177-3188.

Ruiz-Olmo, J., Batet, A., Manas, F., Martinez-Vidal, R., 2011. Factors affecting otter (Lutra lutra) abundance and breeding success in freshwater habitats of the northeastern Iberian Peninsula. Eur. J. Wildlife Res. 57, 827-842.

Ruzycki, J.R., Beauchamp, D.A., Yule, D.L., 2003. Effects of introduced lake trout on native cutthroat trout in Yellowstone Lake. Ecol. Appl. 13, 23-37.

Sheldon, W.G., Toll, W.G., 1964. Feeding habits of the river otter in a reservoir in central Massachusetts. J. Mammal. 45, 449-455.

Simberloff, D. et al., 2013. Impacts of biological invasions: what's what and the way forward. Trends. Ecol. Evol 28, 58-66.

Soulé, M.E., Estes, J.A., Miller, B., Honnold, D.L., 2005. Stongly interacting species: conservation, policy and management. BioScience 55, 168-176.

Sugimoto, T., Aramilev, V.V., Kerley, L.L., Nagata, J., Miquelle, D.G., McCullough, D.R., 2014. Noninvasive genetic analyses for estimating population size and genetic diversity of the remaining Far Eastern leopard (Panthera pardus orientalis) population. Conserv. Genet. 15, 521-532. 
Tabor, J.E., Wight, H.M., 1977. Population status of river otter in western Oregon. J. Wildlife Manage. 41, 692-699.

Teisberg, J.E., Haroldson, M.A., Schwartz, C.C., Gunther, K.A., Fortin, J.K., Robbins, C.T., 2014. Contrasting past and current numbers of bears visiting Yellowstone cutthroat trout streams. J. Wildlife Manage. 78, 369-378.

Waits, L.P., Luikart, G., Taberlet, P., 2001. Estimating the probability of identity among genotypes in natural populations: cautions and guidelines. Mol. Ecol. 10, 249-256.

Wengeler, W.R., Kelt, D.A., Johnson, M.L., 2010. Ecological consequences of invasive lake trout on river otters in Yellowstone National Park. Biol. Conserv. 143, 1144-1153.

White, G.C., Burnham, K.P., 1999. Program MARK: survival estimation from populations of marked animals. Bird Study 46, S120-S139.

Wilcove, D.S., Rothstein, D., Dubow, J., Phillips, A., Losos, E., 1998. Quantifying threats to imperiled species in the United States. Bioscience 48, 607-615. 


\section{Table 1}

Comparison of 5 Cormack-Jolly-Seber models with delta QAICc $<5$ fitted to individual capture histories for river otters in Yellowstone Lake, Yellowstone National Park, 2002-2003 and 20062008, with their respective degrees of freedom $(d f)$, Akaike's Information Criteria adjusted for overdispersion and small sample size $\left(\mathrm{QAIC}_{\mathrm{c}}\right)$, with $\mathrm{AIC}_{\mathrm{c}}$ weights $\left(\mathrm{w}_{i}\right)$. In addition to time and sex variation, models include covariates for number of observer days at latrines (effort), percentage of time an animal was captured at an easy access site (access), mean precipitation from June-August (precip), and an index of cutthroat trout population size (spawners).

\begin{tabular}{lcccc}
\hline Model & $d f$ & $\mathrm{AlC}_{\mathrm{c}}$ & $\Delta \mathrm{AlC}_{\mathrm{c}}$ & $w_{i}$ \\
\hline$\varphi($ sex + spawners) p(effort) & 5 & 210.11 & - & 0.411 \\
$\varphi($ sex $)$ (effort) & 4 & 211.16 & 1.04 & 0.244 \\
$\varphi($ sex + spawners + precip) $p$ (effort) & 6 & 211.36 & 1.25 & 0.220 \\
$\varphi($ sex $p$ (sex) & 7 & 214.00 & 3.89 & 0.059 \\
$\varphi($ sex + spawners) $p$ (sex) & 7 & 214.95 & 4.83 & 0.037 \\
\hline
\end{tabular}




\section{Table 2}

Individual covariate weights for apparent survival $(\varphi)$ and recapture probability $(p)$ from 5

Cormack-Jolly-Seber models with delta QAICc $<5$ fitted to individual capture histories for river otters in Yellowstone Lake, Yellowstone National Park, 2002-2003 and 2006-2008.

\begin{tabular}{llcc}
\hline Covariate & \multicolumn{1}{c}{ Description } & Number of models & Summed AICc weight \\
\hline Effort & $\begin{array}{l}\text { Annual number of observer visits to } \\
\text { latrine sites }\end{array}$ & 14 & 0.971 \\
Spawners & $\begin{array}{l}\text { Annual number of spawning trout in } \\
\text { Clear Creek }\end{array}$ & 10 & 0.688 \\
Sex & Male or female otter & 6 & 0.312 \\
Precip & Mean June-August precipitation & 14 & 0.227 \\
\hline
\end{tabular}




\section{List of Figures}

Fig. 1. Location of study area and river otter latrine sites around Yellowstone Lake, in Yellowstone National Park, Wyoming, USA in summers 2002-2010. Otter symbols denote number of individuals identified on latrines. Dots represent active latrines from which individual genotypes were not obtained (following Haroldson et al., 2005).

Fig. 2. Population size (mean $\pm 95 \%$ confidence intervals) for river otters in Yellowstone Lake and tributary streams, 2002-2003 and 2005-2008. Estimates determined from the CormackJolly-Seber (CJS) open population model and TIRM closed-captures model fit in program Capwire. See text for description of model parameters.

Fig. 3. Fecal deposition rate (A) and density of river otter latrine sites (B) on Yellowstone Lake and tributary streams, summers 2002-2010. Cutthroat trout indices from Koel et al. (2012). Fecal deposition rate shown as mean \pm SE.

Fig. 4. Frequency of occurrence (mean $\pm 95 \%$ confidence intervals) of prey items in scats collected from river otter latrine sites on Yellowstone Lake and tributary streams, summer 20022003 and 2006-2008. 
Fig. 1.

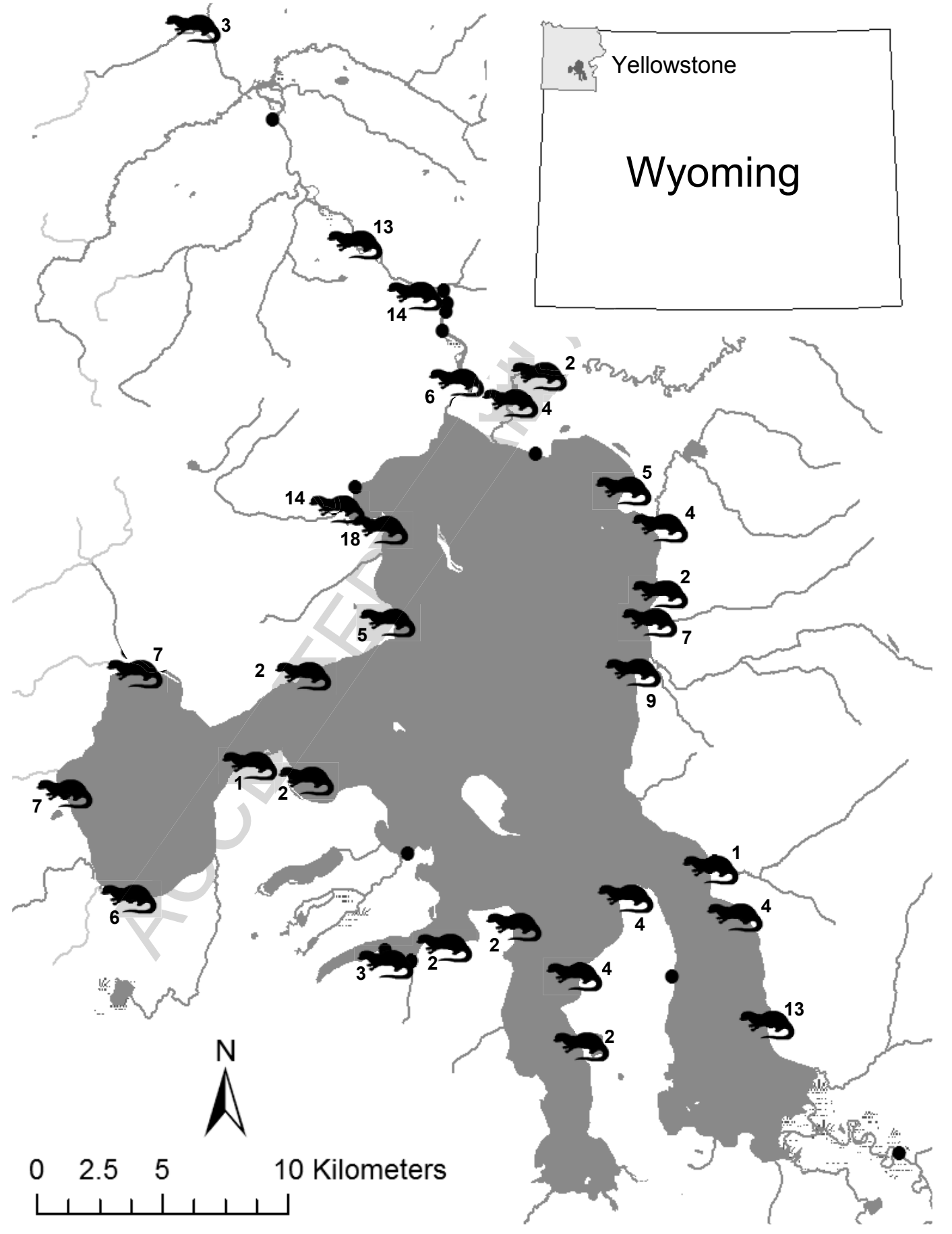


Fig. 2.

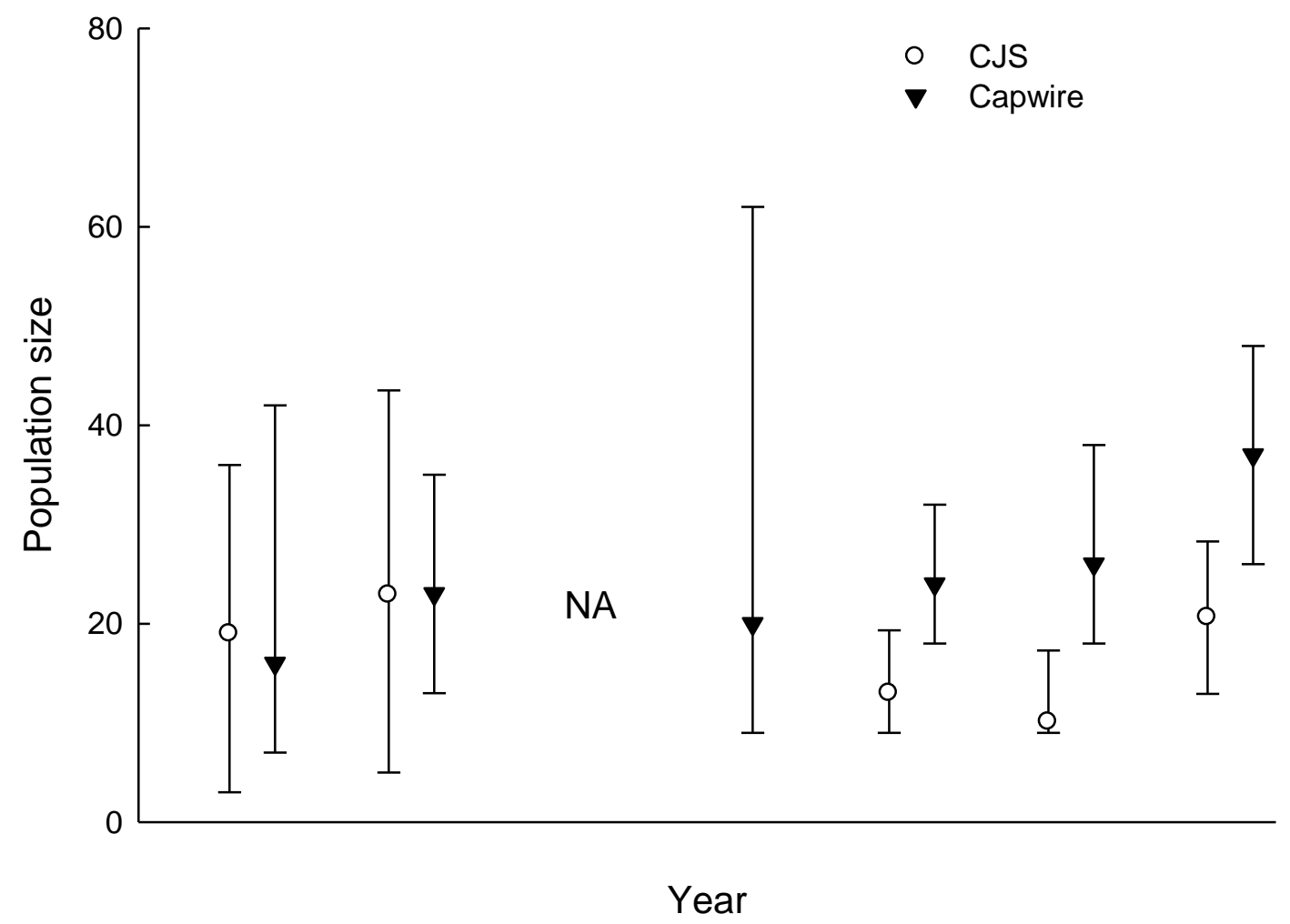


Fig. 3A.
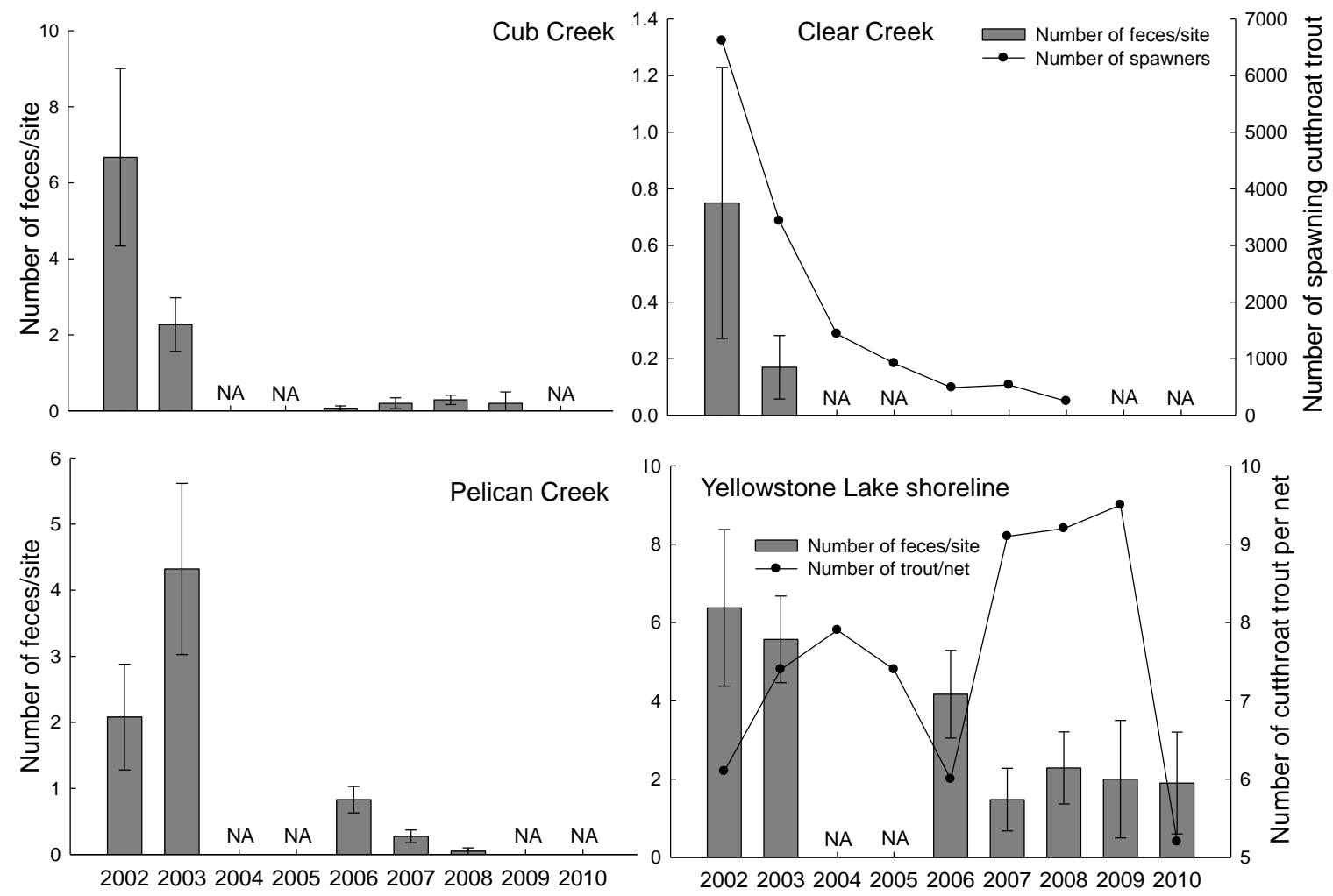

Fig. 3B.
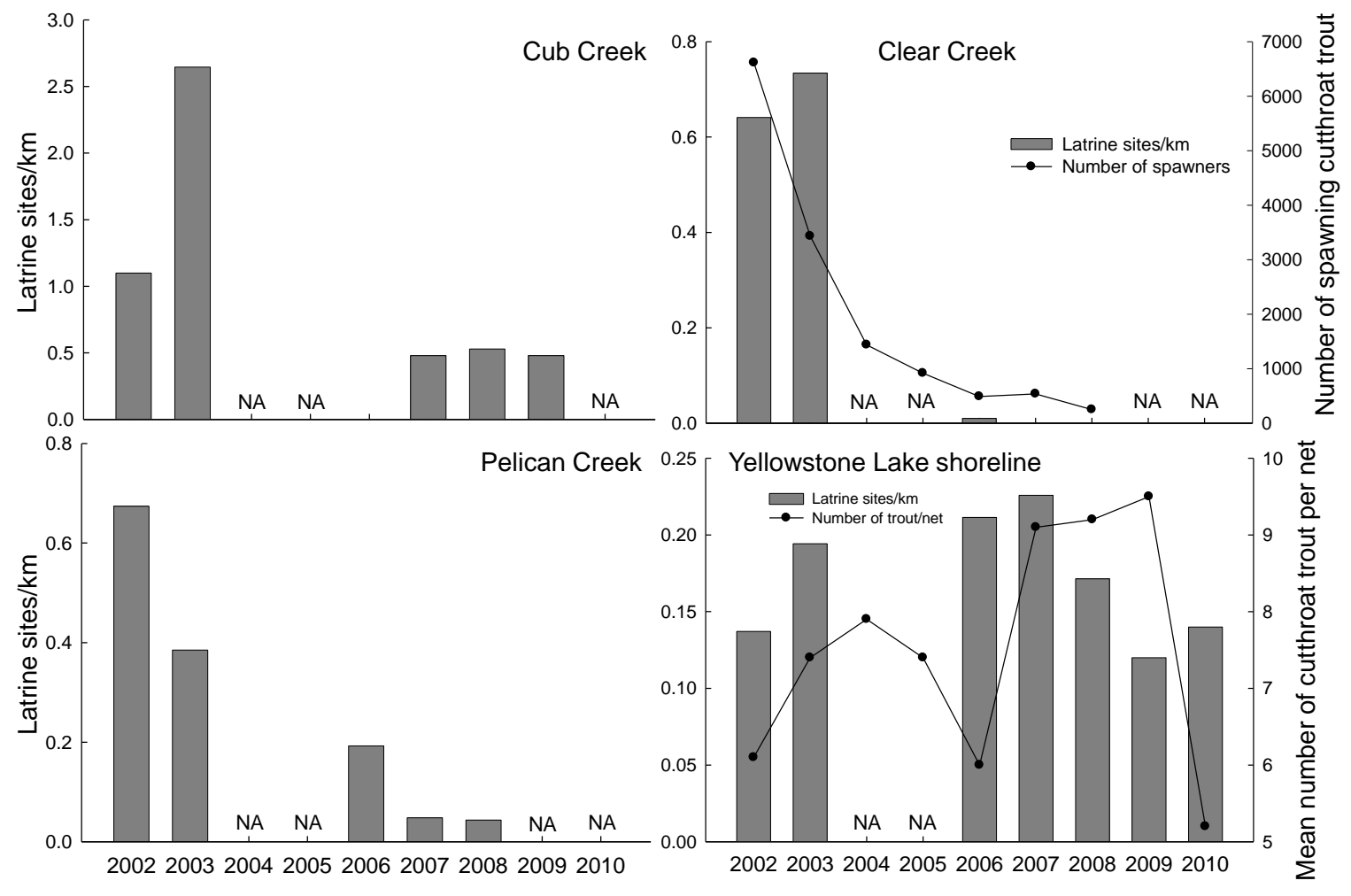
Fig. 4.

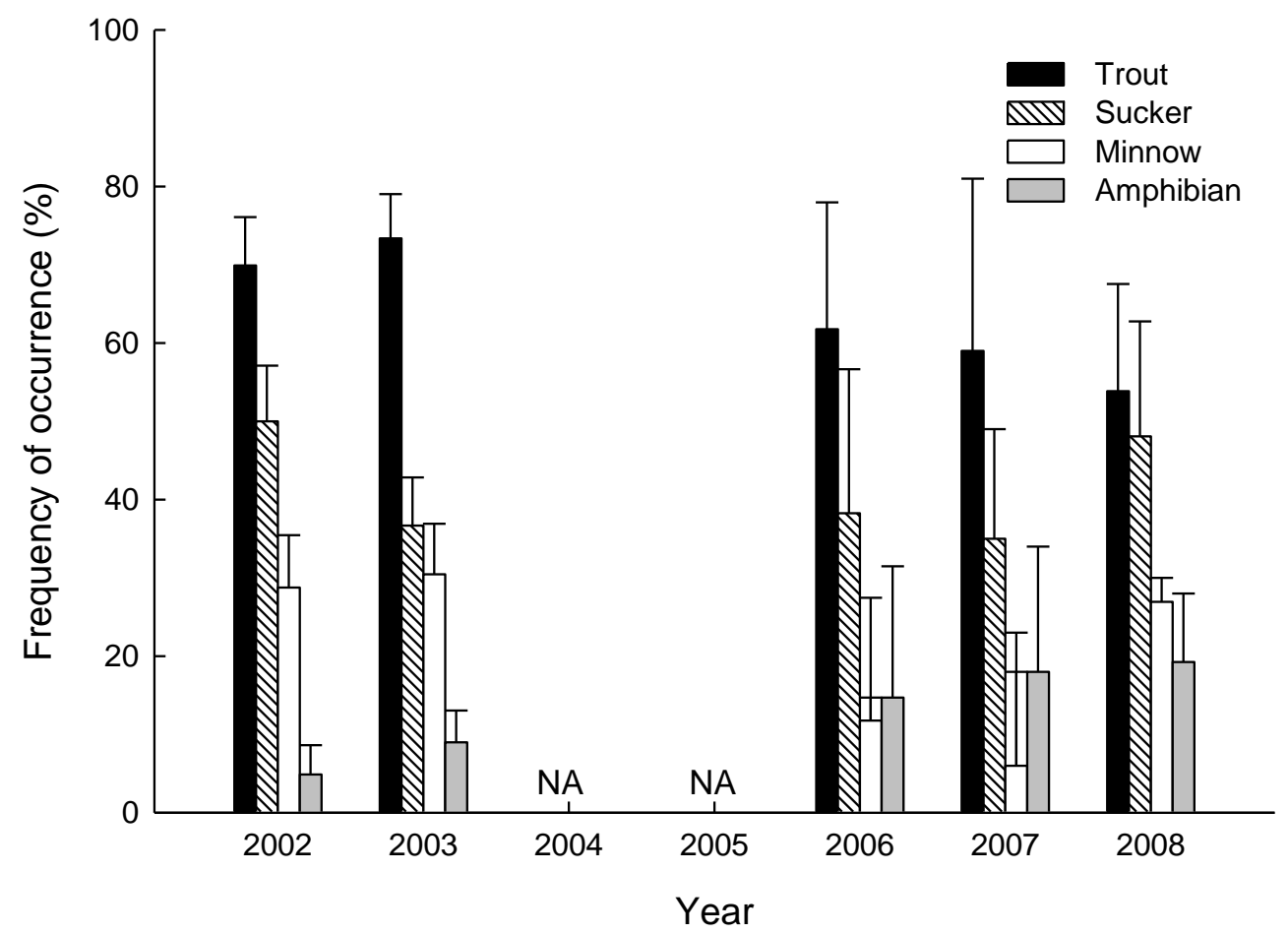

